УДК: 616-036.8:616.9(497.11)"2020"

DOI: https://doi.org/10.18485/fb_covid19.2020.ch4

\title{
АНАЛИЗА СТОПЕ МОРТАЛИТЕТА ЗАРАЗНЕ БОЛЕСТИ КОВИД 19 У БЕОГРАДУ У ПЕРИОДУ МАРТ-ЈУН 2020. ГОДИНЕ СА ДОСТУПНИМ ПОДАЦИМА ДО 31. АВГУСТА 2020. ГОДИНЕ
}

\author{
др Предраг Кон ${ }^{1,}$ \\ др Зоран Кокић
}

Апстракт: Озбиљност сваке пандемије се поред масовности оболевања изражава и кроз смртност, а посебно директну и индиректну смртност. Циљ рада: приказ доступних података о умирању у току епидемије од заразне болести ковид 19 у Београду за период март-јун 2020. године и утврдити да ли је у наведеном периоду постојао вишак опште смртности и вишак смртности од пнеумонија у односу на просек у периоду март-јун 2016-2019. Материјал и метод рада: У раду је коришћен дескриптивни епидемиолошки метод. За податке о морталитету коришћени су подаци Центра за информатику и статистику Завода за јавно здравље Београд из базе умрлих лица. Закључак: Након анализе стопе морталитета заразне болести ковид 19 у Београду у периоду март-јун 2020. године може се проценити да је терет смртности од ове болести у Србији значајан и већи од оног који је евидентиран у току свакодневног надзора, па је врло важно да се темељно истражи. Предлаже се темељна ревизија смртности за територију Републике Србије по претходно јединствено утврђеној методологији у складу са препорукама СЗО.

Кључне речи: ковид 19, пандемија, смртност, ДЕМ2 образац, Београд

\section{УВОД}

Светска здравствене организација (С30) је 30. јануара 2020. изјавом генералног директора прогласила епидемију новог коронавируса као међународну ванредну опасност по јавно здравље према Међународном здравственом правилнику (2005), пратећи савете Одбора за ванредне ситуације. Након привремених препорука Народној Републици Кини послата је мултидисциплинарна техничка

\footnotetext{
${ }^{1}$ Градски завод за јавно здравље, Београд; e-mail: konpredrag@gmail.com

2 Дом здравља, Вождовац.
} 
мисија С3О у Кину да подржи истраживања животињског извора епидемије и испита клинички спектар болести и њену озбиљност, начин преношења са човека на човека у заједници, посебно у здравственим установама, и напоре за сузбијање епидемије. ${ }^{3}$ У фебруару је СЗО издала документ „Стратешка приправност и планирани одговор на нови коронавирус."4 У одређеним специфичним околностима, као што су неизвесност о тежини болести и њеној преносивости, мере које ограничавају кретање људи могу се показати привремено корисним на почетку епидемије, како би се омогућило време за спровођење активности припреме и ради ограничења међународног ширења потенцијално високо заразних случајева.

Ковид 19 је прва документована пандемија изазвана коронавирусом. С30 је привремено назвала нови вирус као нови коронавирус (2019-nCoV) 12. јануара 2020 , а затим и званично назвала ову заразну болест коронавирусном болешћу 2019 (COVID-19) 12. фебруара 2020.5 Међународни комитет за таксономију вируса је на основу филогенетске анализе нови коронавирус званично назвао: тешки акутни респираторни синдром коронавирус 2 (SARS CoV-2). Сматра се да SARS CoV2 вирус потиче од животињског коронавируса који се касније прилагодио и стекао способност преноса са човека на човека. 6 Врло је могуће да ће овај вирус континуирано циркулисати у људској популацији у будућности. Специфични антивирусни третмани и вакцине су још увек у фази припреме; испитивања, изолација, карантин и физичко дистанцирање су и даље једине мере да се спречи ширење вируса. Озбиљност сваке пандемије се поред масовности оболевања изражава и кроз смртност, а посебно директну и индиректну смртност.

\section{ЦИљ РАДА}

Наш задатак је приказ доступних података о умирању у току епидемије од заразне болести ковид 19 у Београду за период март-јун 2020. године и да утврдимо да ли је у наведеном периоду постојао вишак опште смртности и вишак смртности од пнеумонија у односу на просек у периоду март-јун 2016-2019.

3 "Timeline: WHO's COVID-19 response", World Health Organization, https://www.who.int/emergencies/diseases/novel-coronavirus-2019/interactive-timeline, $10 / 09 / 2020$.

4 "2019 Novel Coronavirus (2019-nCoV): Strategic Preparedness and Response Plan", World Health Organizations, $3^{\text {rd }}$ February 2020, https://www.who.int/docs/defaultsource/coronaviruse/srp-04022020.pdf, 10/09/2020.

5 Yen-Chin Liu, Rei-Lin Kuo and Shin-Ru Shih, "COVID-19: The first documented coronavirus pandemic in history", Biomedical Journal, Vol. 43, No. 4, 2020, pp. 328-333.

6 "Homepage", International Committee on Taxonomy of Viruses ICTV, https://talk.ictvonline.org, $10 / 09 / 2020$. 


\section{ИЗВОР ПОДАТАКА}

Појединачне пријаве образаца ДЕМ2 доспелих у Градски завод за јавно здравље, у којима се као основни узрок смрти наводе шифра У071 (лабораторијски потврђени случај ковид 19) и шифра У072 (лабораторијски непотврђени случај ковид 19), као и случајеви пнеумонија са дијагнозом основне смрти: вирусно запаљење плућа некласификовано на другом месту - J12, бактеријска упала плућа некласификовано на другом месту - J15, запаљење плућа неозначеним микроорганизмом - J18 и неозначене интерстицијске болести плућа - J84.9.

\section{МЕТОД РАДА}

У раду је коришћен дескриптивни епидемиолошки метод на основу анализе ДЕМ2 образаца (статистичких образаца о случају смрти које попуњава матичар и потврда о смрти које попуњава лекар) који су пристигли до 31. августа 2020. године. Обрађене су потврде о смрти настале до 30. јуна 2020. године. У овом раду су коришћени само подаци потврда о смрти из ДЕМ-2 образаца, јер су у потпуности комплетирани за период март-јун 2020. године.

Потврде о смрти из образаца ДЕМ2 су документ без кога је у Србији немогуће обавити сахрану и посебно је дефинисано упутство за попуњавање образаца ДЕМ2 на основу Правилника о поступку издавања и обрасцу потврде о смрти.7 Према упутству за попуњавање и достављање потврда о смрти процедура је следећа:

„Уписивање дијагноза узрока смрти (непосредног, претходног и основног као и других значајних стања, болести и повреда које су допринеле смрти и шифрирање истих, а према Дефиницијама из МКБ 10) је обавеза лекара који попуњава потврду. Статистику обрасца ДЕМ-2 и потврду о смрти прослеђује надлежном заводу (Институту за заштиту здравља) ради контроле. У року од тридесет дана Завод/Институт за заштиту здравља у обавези је да обрасце ДЕМ-2 и потврду о смрти врати статистици са преконтролисаним и унетим, где је недостајало, шифрама узрока смрти. Институти/заводи за заштиту здравља податке из контролисаних потврда уносе у софтвер потврда о смрти. Потврду о смрти издаје лекар овлашћен за стручно утврђивање времена и узрока смрти умрлих изван здравствене организације, односно здравствена организација, ако је лице у њој умрло. Без потврде о смрти не може се извршити упис у матичну књигу умрлих“. ${ }^{8}$

7 „Правилник о поступку издавања и обрасцу потврде о смрти (2005)“, Службени гласник СР Србије, бр. 8/2005, Београд, 28. јануар 2005.

8 „Упутство за попуњавање и достављање потвда о смрти“, Институт за јавно здравље „Др Милан Јовановић Батут“, 15. октобар 2010, http://www.batut.org.rs/download/uputstva/Uputstvo\%20potvrda\%20o\%20smrti.pdf, 12/09/2020, стр. 2. 
Овај посао вођења морталитетне статистике се деценијама спроводи у надлежним заводима и институтима за јавно здравље. За све потребе пријављивања болести и шифрирања морталитета за ковид 19 издато је упутство за шифрирање према Међународној класификацији болести МКБ 10 крајем марта 2020. године. ${ }^{9}$

Поред анализе опште смртности, анализирани су основни и непосредни узроци смрти наведени у потврдама о смрти и утврђиван је вишак смртности у случају ковида 19 и у случају следећих пнеумонија: вирусно запаљење плућа некласификовано на другом месту - J12, бактеријских упала плућа некласификованих на другом месту - J15, запаљење плућа неозначеним микроорганизмом - J18 и неозначене интерстицијске болести плућа - J84.9.

\section{АНАЛИЗА ПРИСТИГЛИХ ДЕМ2 ОБРАЗАЦА СА ПОТВРДАМА СМРТИ ОД КОВИД 19 ПРИСТИГЛИХ ДО 31. АВГУСТА 2020.}

Највише потврда о смрти из ДЕМ 2 образаца са основним или непосредним узроком смрти ковид 19, по МКБ шифри У071 и У072, било је у априлу 2020. године (120 особа) за период март-јун. Најмање регистрованих умрлих на основу ових образаца било је у марту (њих 14). Недеља са највише смртних исхода је била шеснаеста (1319. април), када је умрло 32 особе. После 12. недеље (16-22. март), када је регистрован први и једини случај у тој недељи, најмање смртних случајева било је у 23. недељи (1-7. јун), када је регистровано 3 смртна случаја. (графикони 1, 2)

Графикон 1: Број регистрованих умрлих на основу ДЕМ 2 образаца са основним или непосредним узроком смрти ковид 19 (У071 и У072) у Београду по месецима у 2020. години

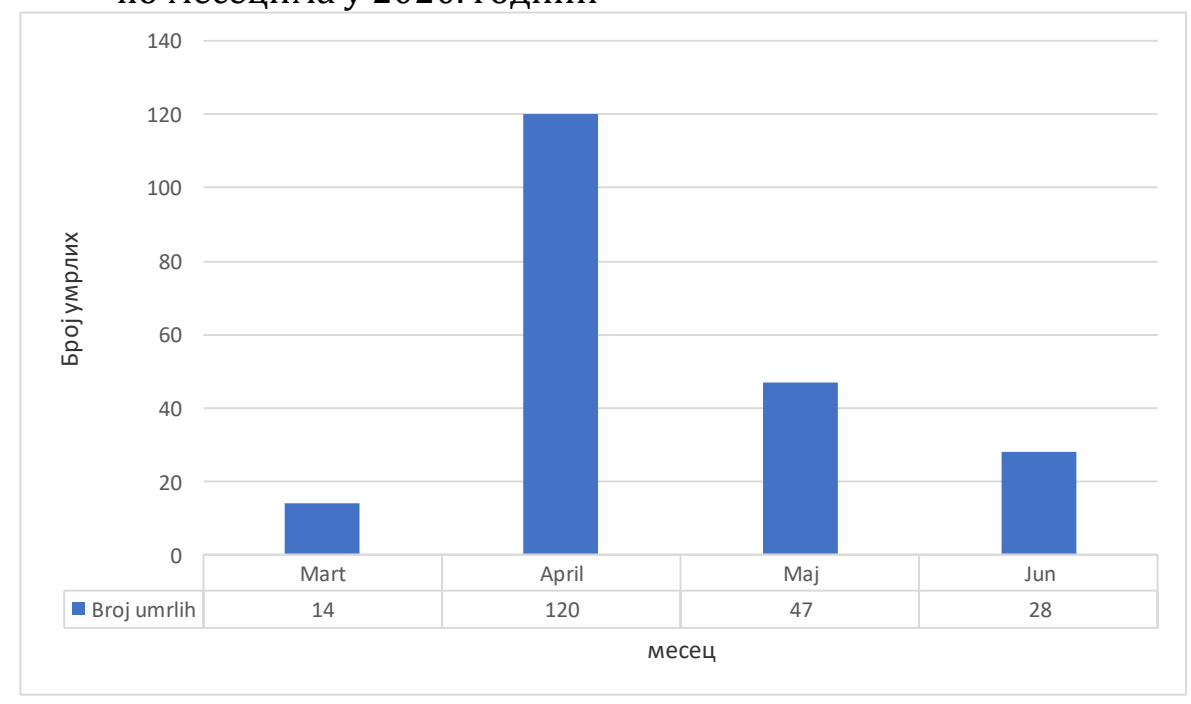

9 “COVID-19 šifriranje prema MKB-10“, Институт за јавно здравље „Др Милан Јовановић Батут“, 14. мај 2020, http://www.batut.org.rs/download/COVID-19-\%C5\%A1ifriranje-MKB10.pdf, 12/09/2020; „Одлука о проглашењу болести COVID-19 изазваневирусом SARS-CoV-2 заразном болешћу (2020)“, Службени Гласник PC, бр. 116/2020, Београд, 16. септембар 2020. 
Графикон 2: Број регистрованих умрлих на основу ДЕМ 2 образаца са основним или непосредним узроком смрти ковид 19 (У071 и У072) у Београду по недељама у 2020. години.

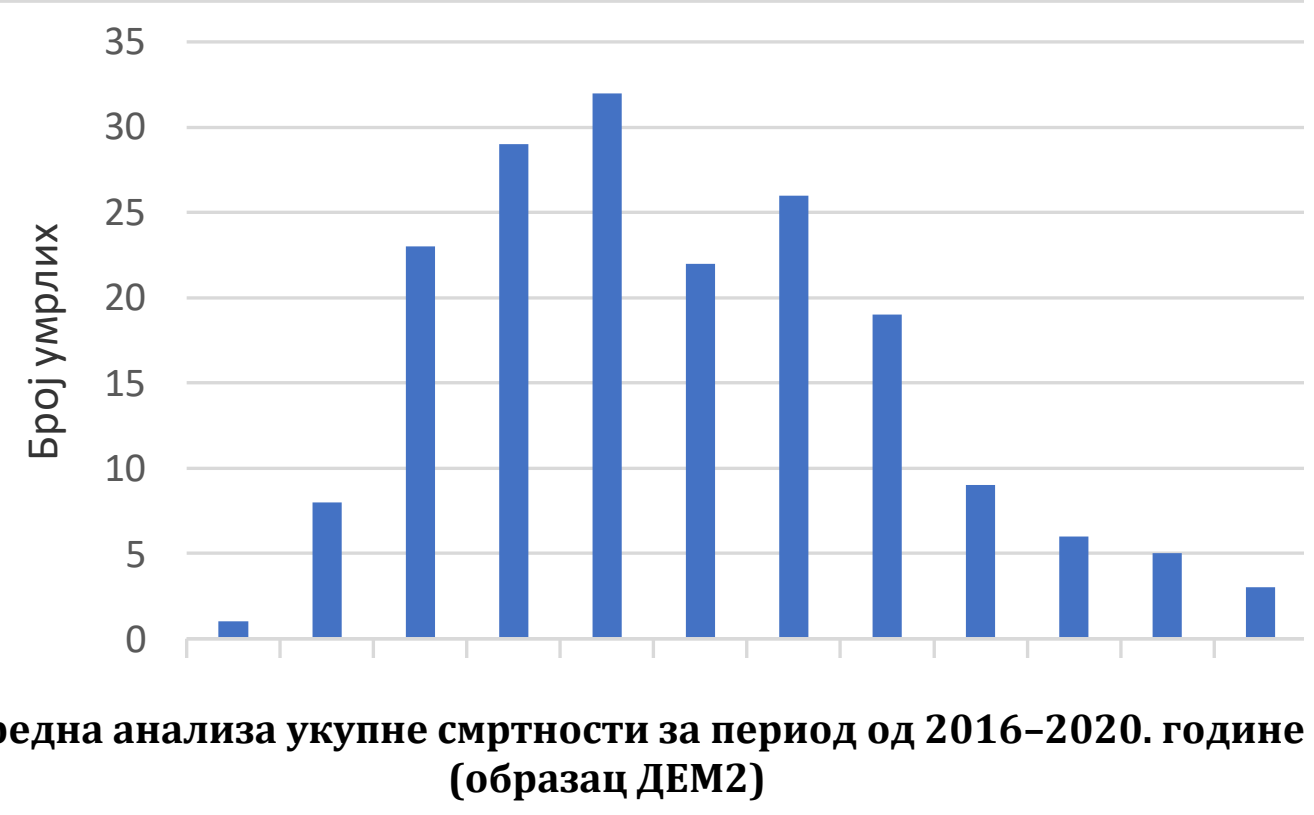

Анализа потврда смрти из образаца ДЕМ2 за период од 2016. до 2020. године приказана је на графиконима 3, 4 и 5. Укупан број умрлих у Београду у априлу 2020. године (1914) био је већи него у истом месецу у осталим годинама наведеног периода, што важи и за стопу морталитета у априлу 2020. године (112,98:100.000).

Месечна стопа укупног морталитета 2020. године већа је од просечне стопе морталитета 2016-2019. године у марту $(112,69$ у односу на просечну 107,60 на $100.000)$, априлу $(112,98$ у односу на 98,77 на 100.000$)$ и јуну $(98,70$ у односу на 93,55 на 100.000). У мају је просечна стопа морталитета 2016-2019. већа од 2020. године $(101,94$ у односу на 96,63 на 100.000). Вишак смртних исхода у апсолутним бројевима је у марту 2020. године у односу на просек 2016-2019. био је 92 особе, у априлу 246 особа, у мају је умрло мање од просека у претходним годинама - 85 особа, и у јуну је више смртних исхода било - 92 у односу на просек ранијих година. 
Графикон 3: Број укупно умрлих по месецима март-јун у Београду у периоду од 2016. до 2020. године

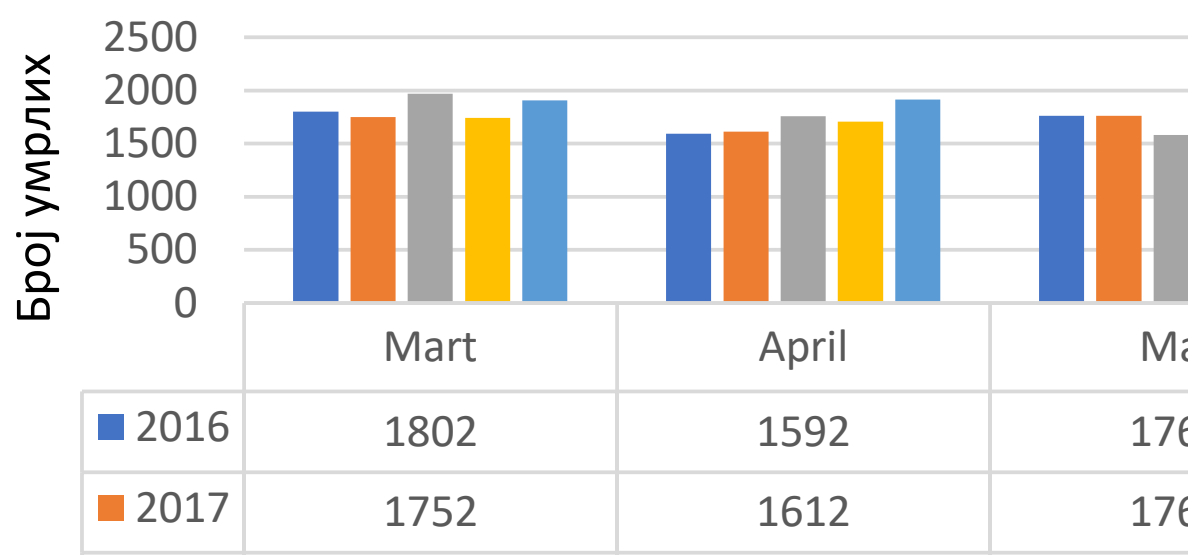

Графикон 4: Месечна стопа укупног морталитета 1:100.000 за период март-јун од 2016. до 2020. године

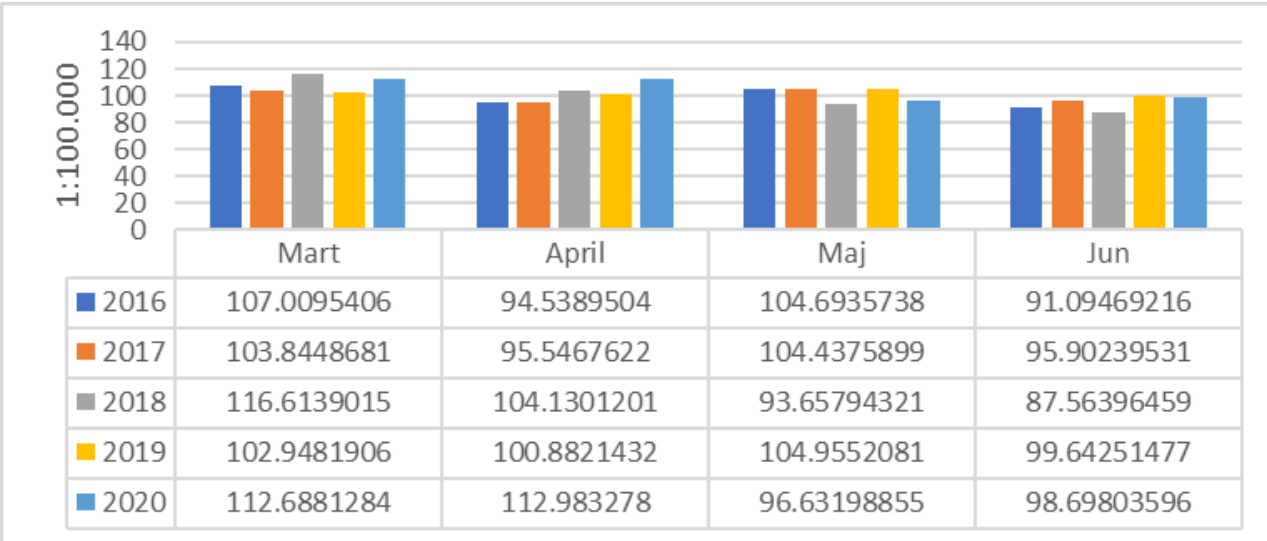

Графикон 5: Просечна стопа укупног морталитета 1:100.000 по месецима мартјун за период 2016-2019 упоређена са стопом морталитета за исте месеце 2020. године

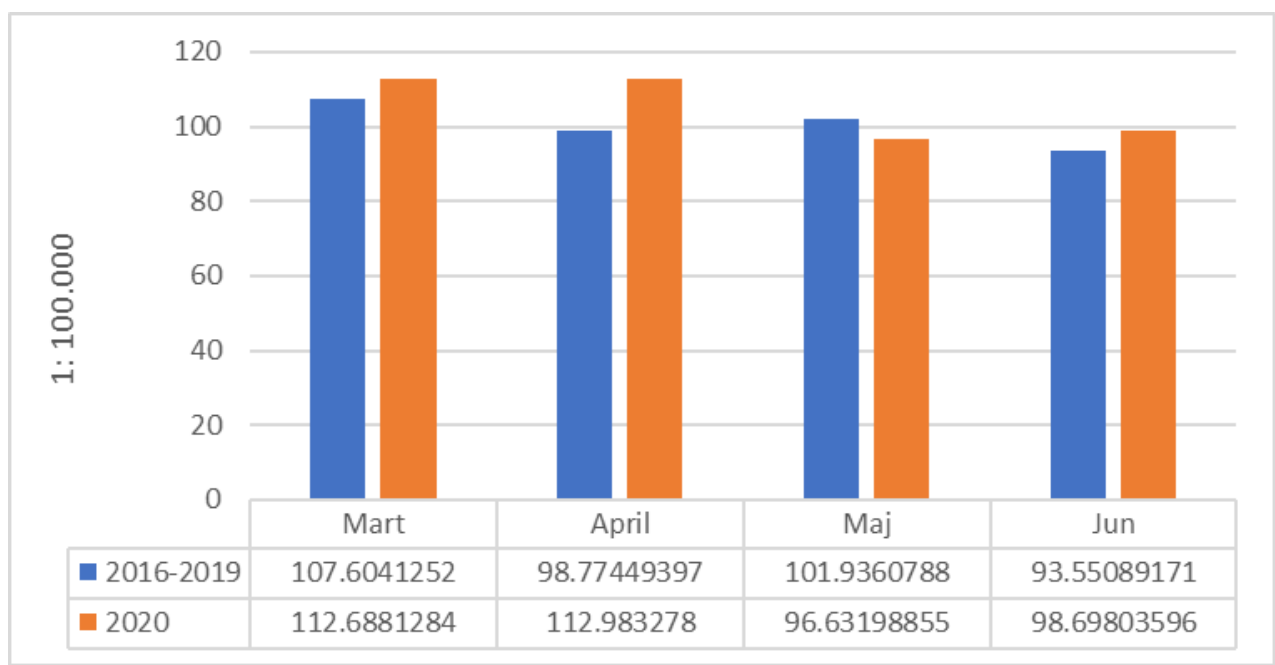




\section{Основни узрок смрти J12 \\ (вирусно запаљење плућа некласификовано на другом месту)}

У периоду пре 2020. године који је обрађен (2016-2019) није било ниједног случаја ДЕМ 2 обрасца са уписаним основним узроком смрти J12 (вирусно запаљење плућа некласификовано на другом месту) у периоду март-јун. За разлику од тога, у 2020. години у априлу је регистровано 22, у мају 6 и у јуну 1 смртни случај са овом дијагнозом (графикон 6).

Графикон 6: број умрлих у Београду са основним узроком смрти J12 (вирусно запаљење плућа некласификовано на другом месту) у периоду мартјун од 2016. до 2020. године.

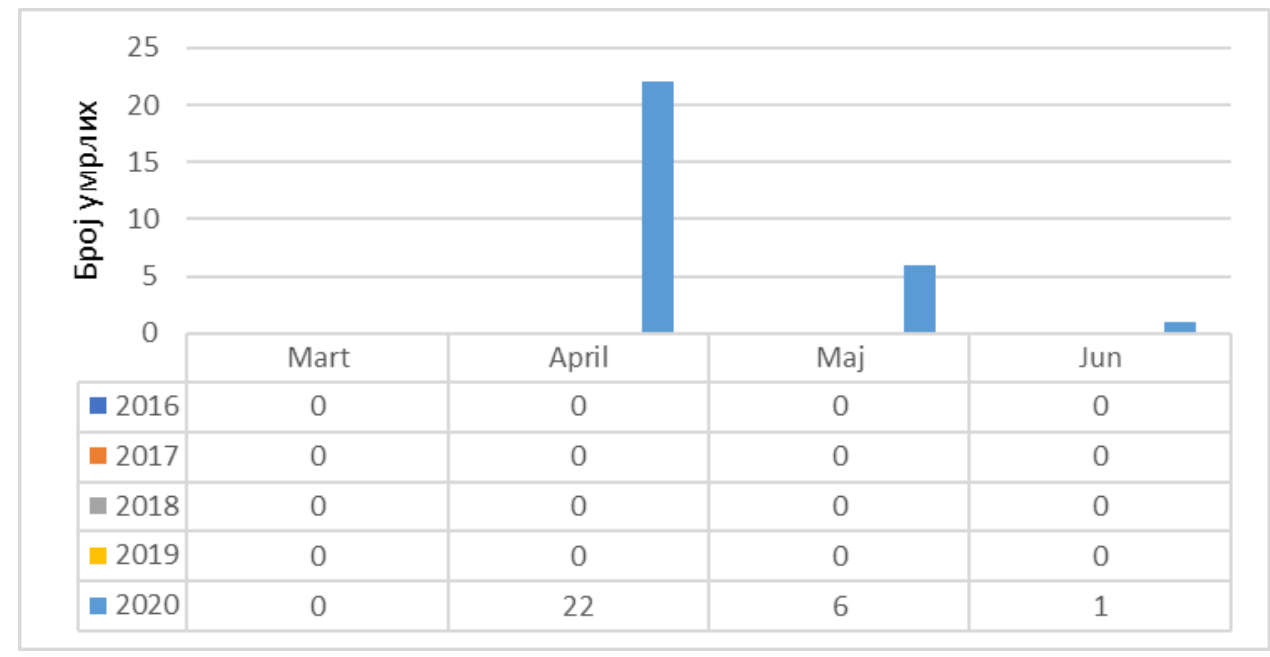

\section{Основни узрок смрти J15 \\ (бактеријска упала плућа некласификовано на другом месту)}

Анализа потврда смрти из образаца ДЕМ2 са основним узроком смрти J15 (бактеријска упала плућа некласификовано на другом месту) у периоду март-јун од 2016. до 2019. године приказана је на графиконима 7, 8 и 9. Укупан број умрлих у Београду са основним узроком смрти од бактеријског запаљења плућа некласификовано на другом месту био је у марту 2020. године 5, што је исто као 2017. године, али веће него 2016. - 2, 2018. - 2 и 2019. - 3. У априлу 2020. био је 1 случај регистроване смрти; исто као и 2016, док је 2017. - 3, 2018. - 2 и 2019. - 3.У мају 2020. године није регистрована смрт по овој дијагнози, за разлику од осталих година, док је у јуну 2020. било 3 случаја смрти, а 2016. - 0, 2017. - 5, 2018. - 2 и 2019. - 2 (графикон 7). Морталитет по месецима и наведеним годинама приказан је на графикону 8. 
Графикон 7: Број умрлих у Београду са основним узроком смрти J15 (бактеријска упала плућа некласификовано на другом месту) у периоду март-јун од 2016. до 2020. године

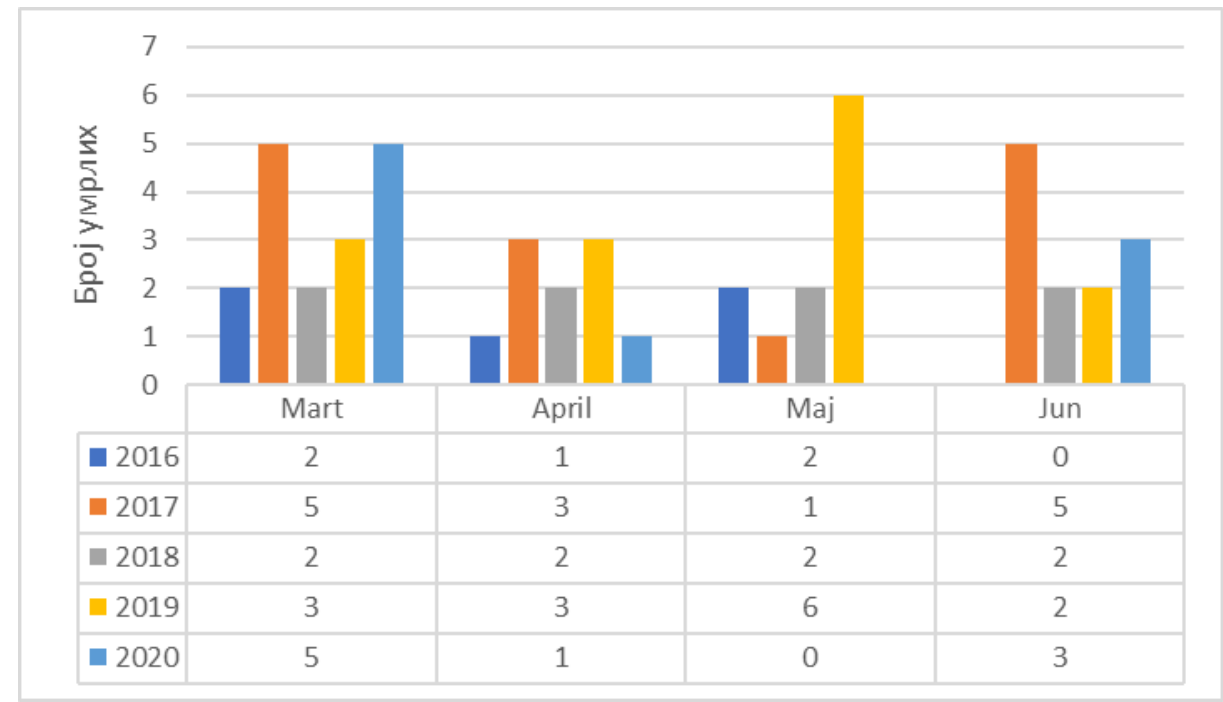

Графикон 8: Стопа месечног морталитета 1:100.000 са основним узроком смрти J15 (бактеријско запаљење плућа некласификовано на другом месту) у периоду март-јун од 2016. до 2020. године

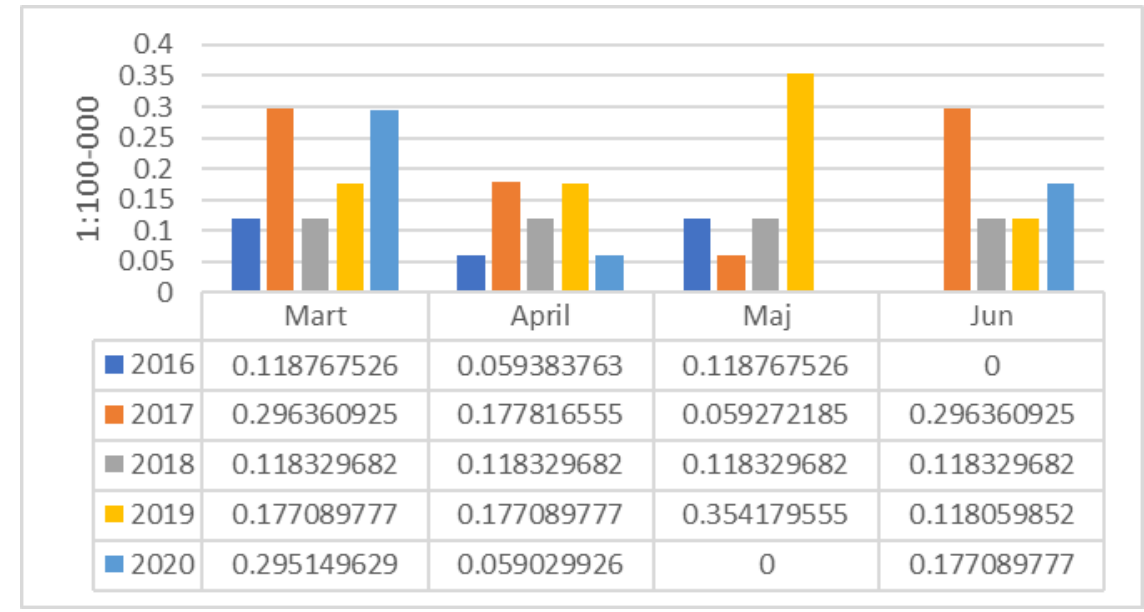

Месечна стопа морталитета 2020. године са основним узроком смрти J15 (бактеријска упала плућа некласификовано на другом месту) већа је од просечне стопе морталитета 2016-2019. године у марту $(0,30$ у односу на просечну 0,18 на $100.000)$ и јуну (0,18 у односу на 0,13 на 100.000$)$. (графикон 9). 
Графикон 9: Просечна стопа месечног морталитета 1:100.000 са основним узроком смрти J15 (бактеријско запаљење плућа некласификовано на другом месту) у периоду март-јун од 2016. до 2020. године упоређена са месечном стопом за исти период у 2020. години

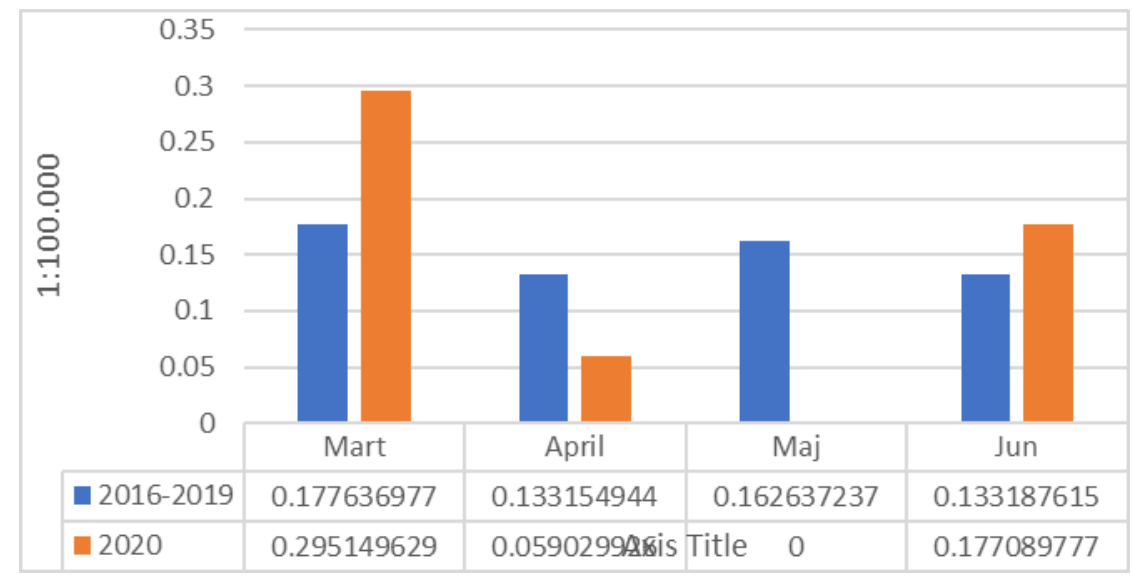

\section{Основни узрок смрти J18 \\ (запаљење плућа неозначеним микроорганизмом)}

Анализа потврда смрти из образаца ДЕМ2 са основним узроком смрти J18 (запаљење плућа неозначеним микроорганизмом) у периоду март-јун од 2016. до 2019. године приказана је на графиконима 10, 11 и 12. Укупно је у 2020. у наведеном периоду било 204 болесника са овим основним узроком смрти. Број умрлих у Београду са основним узроком смрти од запаљења плућа неозначеним микроорганизмом био је већи у марту - 54, априлу - 87 и мају 33 у 2020 . години него у истим месецима у осталим годинама (2016-2019), што важи и за стопу морталитета (графикон 11). Вишак умрлих у односу на просек 2016-2019. за период март-јун износио је 102.

Месечна стопа морталитета 2020. године са основним узроком смрти J18 (запаљење плућа неозначеним микроорганизмом) већа је од просечне стопе морталитета 2016-2019. године у марту $(3,19$ у односу на просечну 1,89 на $100.000)$, априлу $(5,14$ у односу на 1,54 на 100.000$)$, мају (1,95 у односу на 1,27 на $100.000)$ и јуну (1,77 у односу на 1,32 на 100.000$)$ (графикон 12$)$. 
Графикон 10: Број умрлих у Београду са основним узроком смрти J18 (запаљење плућа неозначеним микроорганизмом) у периоду март-јун од 2016. до 2020. године

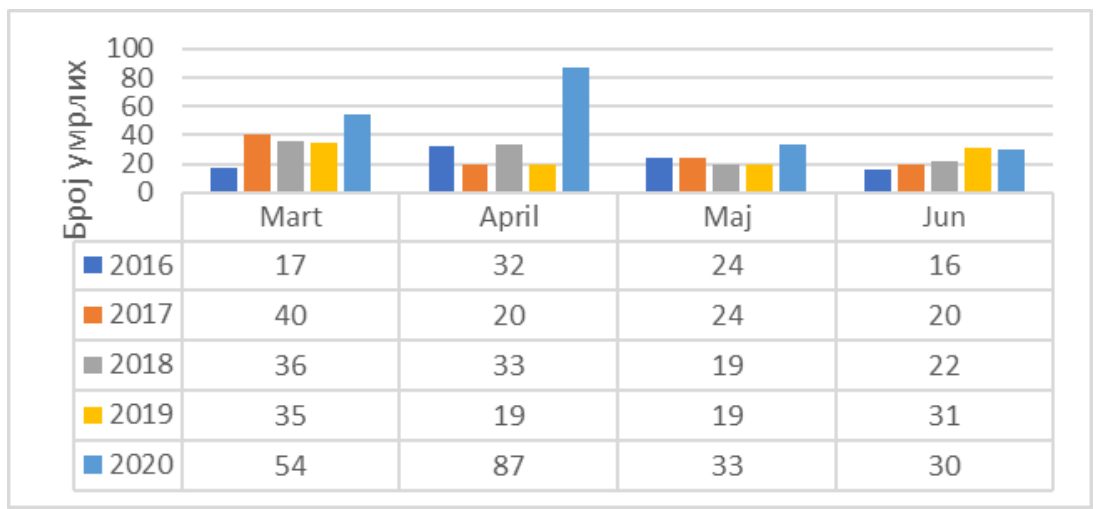

Графикон 11: Стопа месечног морталитета 1:100.000 са основним узроком смрти J18 (запаљење плућа неозначеним микроорганизмом) у периоду март-јун од 2016. до 2020. године

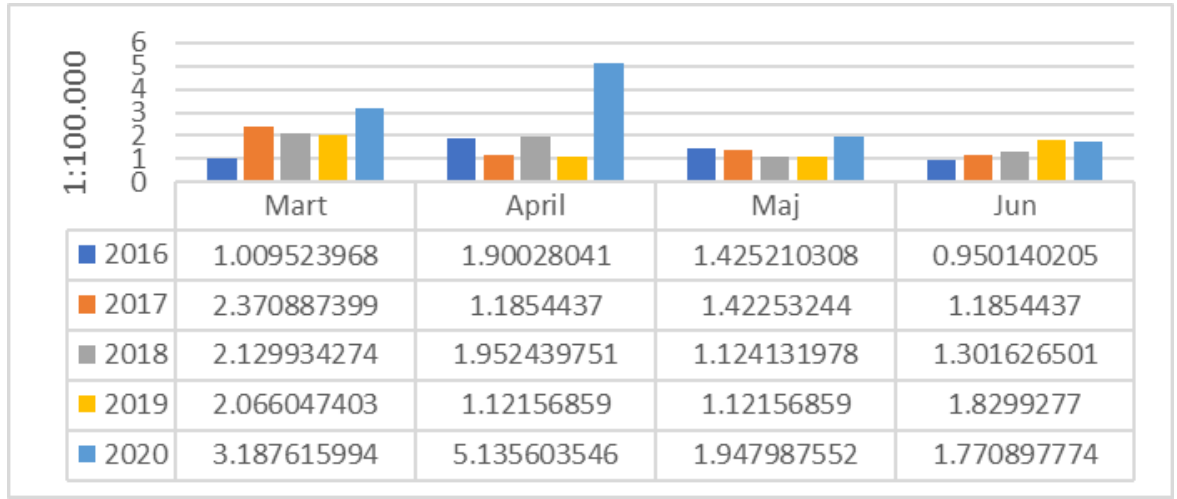

Графикон 12: Просечна стопа месечног морталитета 1:100.000 са основним узроком смрти J18 (запаљење плућа неозначеним микроорганизмом) у периоду март-јун од 2016. до 2019. године упоређена са месечном стопом за исти период у 2020. години.

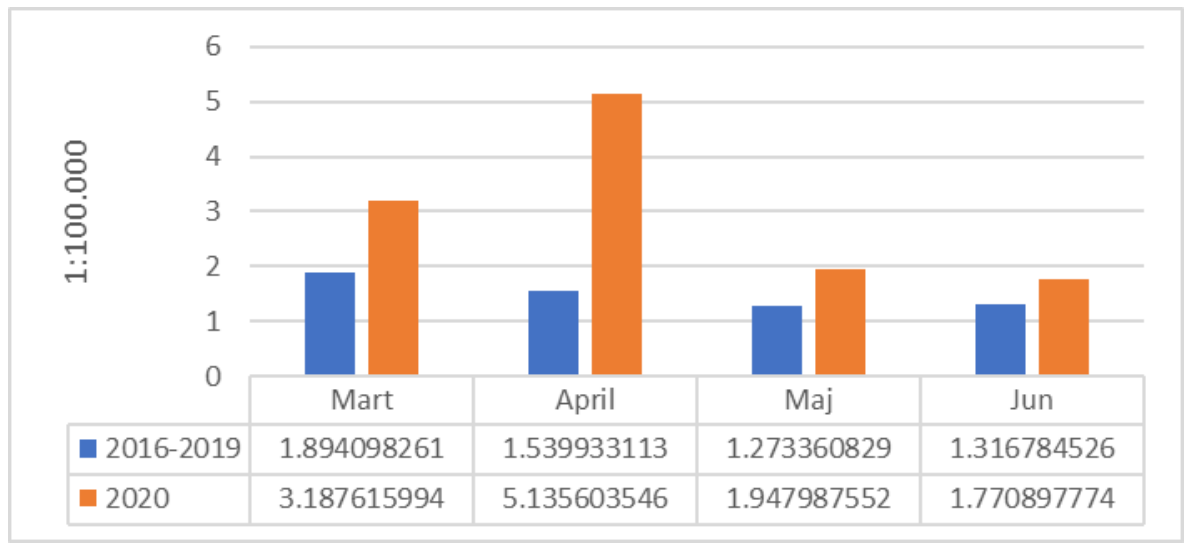




\section{Основни узрок смрти J84.9 \\ (неозначене интерстицијске болести плућа)}

У периоду 2016-2020. године било је укупно 4 смртна исхода од неозначене интерстицијске болести плућа 2 у мају 2017. године и 2 у марту 2020. године.

\section{Узраст умрлих са основним и/или непосредним узроком смрти од ковида 19 (У071+У072)}

Највише регистрованих умрлих било је међу старијим од 70 година - 119 (57\%), затим 60-69 година - 41 (20\%), 50-59 година - 30 (14\%), 40-49 година - 11 (5\%), $30-39$ година - $6(3 \%)$ и $20-29$ година - $2(1 \%)$. У осталим дечијим узрастима није било смртних исхода. Било је 80 умрлих од ковида 19 (У07.1+У07.2) женског пола и 130 умрлих мушког пола.

Графикон 14: Број умрлих од ковида 19 (У071+У072) по узрасту, у периоду март-јун 2020. године по обрасцима ДЕМ2

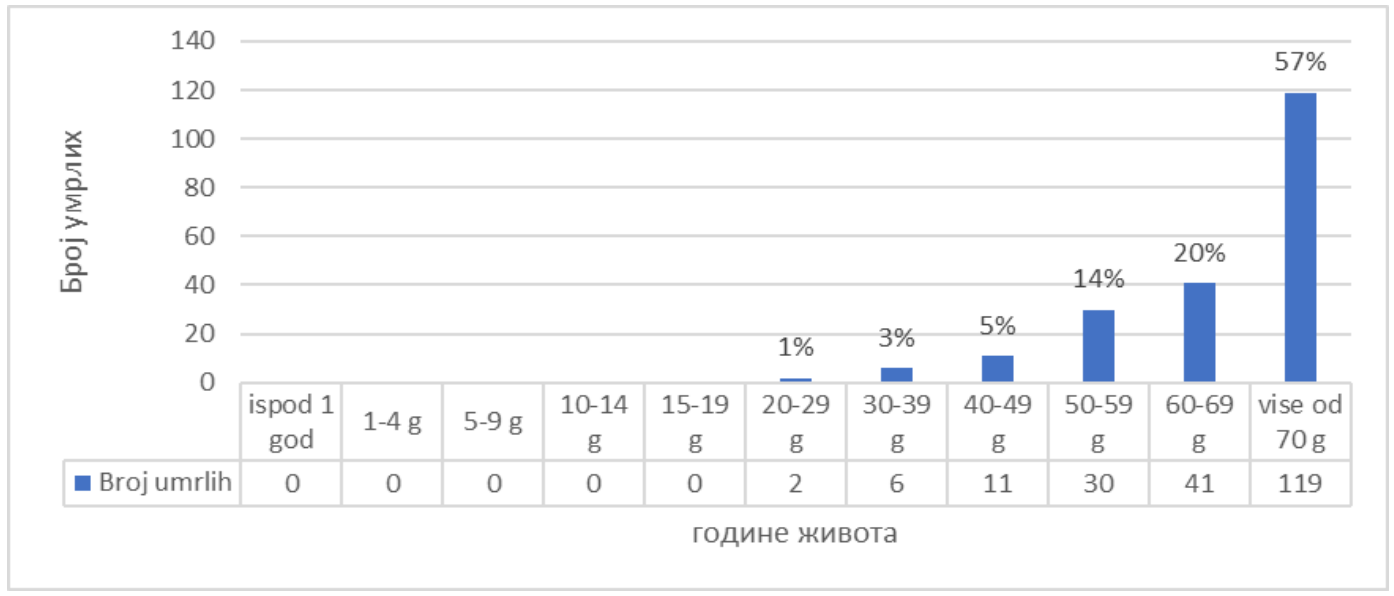

Графикон 15: умрли од ковида 19 (У071+У072) по полу, у периоду март-јун 2020. године по обрасцима ДЕМ2

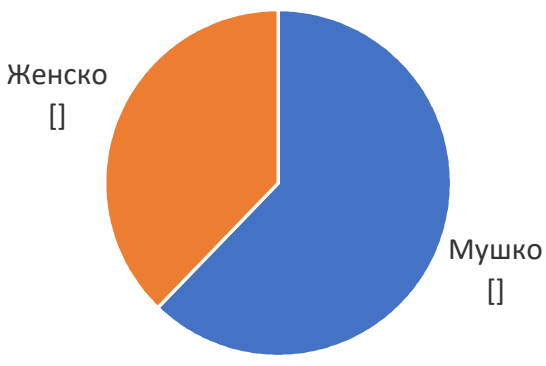




\section{ДИСКУСИјА}

Озбиљност и друштвени терет који доноси заразна болест, посебно у случају пандемије, у овом случају ковид 19 , изазвана новим $S A R S-2-C o V$ вирусом, изражава се и кроз смртност од ове болести. ${ }^{10}$ Процене вишка смртних случајева могу пружити информације о терету смртности који је потенцијално повезан са пандемијом ковида 19, укључујући смртне случајеве који се директно или индиректно приписују ковиду 19. Прекомерна смртност (вишак смртности) се обично дефинише као разлика између уоченог броја умрлих у одређеним временским периодима и очекиваног броја умрлих у истим временским периодима. Процене вишка смртности могу се изражавати за одређени период било кроз број случајева или вишак морталитета који је већи од прага (просека у ранијим годинама).11

Смртност од неке заразне болести процењује се на основу леталитета и морталитета. Леталитет се може изражавати као број умрлих у односу на број оболелих (Case fatality rate-CFR), број умрлих у односу на број инфицираних (Infection fatality rate-IFR). Леталитет се изражава у процентима. Леталитет се може односити и само на хоспитализоване оболеле, али се то онда посебно наглашава. Тешкоће приликом одређивања леталитета је утврђивање тачног броја инфицираних, односно оболелих. Код утврђивања броја инфицираних мора се вршити процењивање, јер је број инфицираних значајно и вишеструко већи од броја оболелих. То се најчешће ради сероепидемиолошким испитивањем прокужености. Код утврђивања броја оболелих користе се подаци пријављених случајева оболевања од заразне болести.

Морталитет се изражава као број умрлих од неке болести на дефинисани број становника, најчешће 100.000. Тешкоће приликом тачног утврђивања морталитета односе се више на то да ли се тачно региструју узроци смрти.

У раду је приказано да је у периоду март-јун 2020. године вишак опште смртности био 345 у односу на просек за исти период 2016-2019. године. Вишка опште смртности било је у марту $92(+5,084 / 100.000)$, априлу $246(+13,209 / 100.000)$ и јуну $92(+5,148 / 100.000)$, док у мају није регистрован. У наведеном периоду мартјун 2020. по подацима изнетим у раду било је 210 смртних случајева у Београду са уписаним узроком смрти ковид 19 (У071 и У072), што ранијих година није било, јер се овај узрок смрти први пут појављује 2020. године.

Од испитаних пнеумонија као основни узрок смрти уочава се да је 29 умрло са дијагнозом J12 - вирусно запаљење плућа некласификовано на другом месту, што претходних година (2016-2019) није било ни у једном случају. Број умрлих са

10 "Estimating mortality from COVID-19", World Health Organization, $4^{\text {th }}$ August 2020, https://www.who.int/publications/i/item/WHO-2019-nCoV-Sci-Brief-Mortality-2020.1, $15 / 09 / 2020$.

11 "Excess Deaths Associated with COVID-19: Provisional Death Counts for Coronavirus Disease (COVID-19)", Centers for Disease Control and Prevention, https://www.cdc.gov/nchs/nvss/vsrr/covid19/excess_deaths.htm, 15/09/2020. 
дијагнозом неозначене упале плућа (J18) је било 204, што је више од просека за период 2016-2019 у 102 случаја. Не уочава се вишак смртности од бактеријске упале плућа (J15) у истом периоду, нити од неозначене интерстицијске болести плућа (J84.9).

Остали узроци смрти нису праћени кроз ову анализу морталитетне статистике за период март-јун 2020, па се не може проценити да ли је било индиректних узрока смрти као последица пандемије ковида 19 у овом периоду. Чини се да их није било, али је могуће да су се касније појавиле после јуна 2020. године, што није обрађено у овом раду. Вероватније је да су смрти због пнеумонија приказане у овом раду повезане директно са ковидом 19, било као недијагностиковани случајеви или компликације.

Глобално праћење оболевања и умирања од ковида 19 у реалном времену са лабораторијски потврђеним и смртним случајевима била је карактеристика ове пандемије глобално. Дневно се могло пратити оболевање и умирање у свету, што је објављивано преко доступних сајтова, С30, Европског центра за контролу болести и других доступних сајтова, портала и других интернет приступа. 121314

Европски центар за контролу болести је повремено објављивао извештаје са пресеком ситуације, где је објављиван и број регистрованих смртних случајева у земљама Европе. У извештају од 2. јула 2020. године 15 број умрлих до 30. јуна 2020. године по земљама је био следећи: Аустрија 703 , Белгија 9 747, Бугарска 223, Хрватска 107, Кипар 19, Чешка 348, Данска 605, Естонија 69, Финска 328, Француска 29 813, Немачка 8 973, Грчка 191, Мађарска 585, Исланд 10, Ирска 1 735, Италија 34 744, Летонија 30, Лихтенштајн 1, Литванија 78, Луксембург 110, Малта 9, Холандија 6 107, Норвешка 249, Пољска 1 444, Португал 1 568, Румунија 1 634, Словачка 28, Словенија 111, Шпанија 28 346, Шведска 5 310, Велика Британија 43 575, Албанија 58, Босна и Херцеговина 183, Косово 1 649, Црна Гора 11, Северна Македонија 298, Србија 274, Турска 5115.

У периоду до 30. јуна 2020. по наведеном извештају Европског центра за контролу болести регистровано је 274 умрлих од ковида 19 у Србији, а у Београду је Градском заводу за јавно здравље пријављено 118 смрти од заразне болести ковид 19. Ова анализа указује да је смртних случајева због ковида 19 највероватније било више.

12 "Covid-19 Coronavirus pandemic" Worldometer, https://www.worldometers.info/coronavirus/, 16/09/2020.

13 "Covid-19 pandemic", European Centre for Disease Prevention and Control, https://www.ecdc.europa.eu/en/covid-19-pandemic, 16/09/2020.

14 "WHO Coronavirus Disease (COVID-19) Dashboard", World Health Organization, https://covid19.who.int/,16/09/2020.

15 "Resurgence of reported cases of COVID-19 in the EU/EEA, the UK and EU candidate and potential candidate countries", European Centre for Disease Prevention and Control, $2^{\text {nd }}$ July 2020 ,

https://www.ecdc.europa.eu/sites/default/files/documents/RRA-Resurgence-of-reportedcases-of-COVID-19-in-the-EU-EEA.pdf, 17/09/2020. 
С30 је 20. априла 2020. издала међународно упутство за сертификацију и класификацију ковида 19 као узрока смрти. ${ }^{16}$ До тада није постојала јединствена дефиниција за регистровање смрти од ковида 19, а примена врло вероватно није почела истог момента када је дефиниција донета. И поред тога се може претпоставити да није једнако коришћена у земљама света, па се велике разлике у приказу смртности по разним земљама света морају узимати са великом резервом.

Потреба за утврђивањем што тачније процене смртности од ковида 19 директне и индиректне значајна је за све земље света и вероватно ће се спроводити у будућности, а посебно након завршетка пандемије. Међутим, ограничења везана за ову анализу која се односи само за територију Београда и становнике Београда налазе се у чињеници да се за овај кратак период (март-јун) не може уочити вишак због индиректне смртности која би се могла повезати са епидемијом ковида 19 због отежане доступности здравственом систему пацијентима са нонковид стањима у време велике оптерећености система због епидемије.

Вероватан разлог лежи у томе што у овом раду осим пнеумонија нису обрађене циркулаторне болести, малигне неоплазме, бубрежне болести, ендокринолошке болести, сепсе и све друге болести. По подацима из опште смртности то се не може закључити, јер се вишак опште смртности за овај кратак период може објаснити вишком смртности због ковида 19, вирусне упале плућа и неозначених пнеумонија, што је у раду и приказано.

\section{ЗАКЉУЧАК}

Након анализе стопе морталитета заразне болести ковида 19 у Београду у периоду март-јун 2020. године може се проценити да је терет смртности од ове болести у Србији већи од оног који је евидентиран у току свакодневног надзора, па је врло важно да се темељно истражи. Предлаже се темељна ревизија смртности за територију Републике Србије по претходно јединствено утврђеној методологији у складу са препорукама СЗО.

\section{ЛИТЕРАТУРА}

"2019 Novel Coronavirus (2019-nCoV): Strategic Preparedness and Response Plan", World Health Organizations, $3^{\text {rd }}$ February 2020.

https://www.who.int/docs/default-source/coronaviruse/srp-04022020.pdf.

"Covid 19 Coronavirus pandemic" Worldometer,

16 "International guidelines for certification and classification (coding) of COVID-19 as cause of death", World Health Organization, 20 ${ }^{\text {th }}$ April 2020,

https://www.who.int/classifications/icd/Guidelines_Cause_of_Death_COVID-19-20200420-

EN.pdf, 17/09/2020. 
https://www.worldometers.info/coronavirus/.

"Covid19 pandemic", European Centre for Disease Prevention and Control, https://www.ecdc.europa.eu/en/covid-19-pandemic.

“COVID 19 šifriranje prema MKB-10“, Институт за јавно здравље „Др Милан Јовановић Батут", 14. мај 2020.

http://www.batut.org.rs/download/COVID-19-\%C5\%A1ifriranje-MKB10.pdf.

"Estimating mortality from COVID-19", World Health Organization, 4th August 2020. https://www.who.int/publications/i/item/WHO-2019-nCoV-Sci-Brief-Mortality-2020.1.

"Excess Deaths Associated with COVID-19: Provisional Death Counts for Coronavirus Disease (COVID-19)", Centers for Disease Control and Prevention, https://www.cdc.gov/nchs/nvss/vsrr/covid19/excess_deaths.htm.

"Homepage", International Committee on Taxonomy of Viruses ICTV, https://talk.ictvonline.org.

"International guidelines for certification and classification (coding) of COVID-19 as cause of death", World Health Organization, 20 th april 2020.

https://www.who.int/classifications/icd/Guidelines_Cause_of_Death_COVID-1920200420-EN.pdf.

"Resurgence of reported cases of COVID-19 in the EU/EEA, the UK and EU candidate and potential candidate countries", European Centre for Disease Prevention and Control, $2^{\text {nd }}$ July 2020, https://www.ecdc.europa.eu/sites/default/files/documents/RRA-Resurgence-ofreported-cases-of-COVID-19-in-the-EU-EEA.pdf.

“Timeline: WHO's COVID-19 response”, World Health Organization,

https://www.who.int/emergencies/diseases/novel-coronavirus-2019/interactivetimeline.

"WHO Coronavirus Disease (COVID-19) Dashboard", World Health Organization, https://covid19.who.int/.

„Правилник о поступку издавања и обрасцу потврде о смрти (2005)“, Службени гласник СР Србије, бр. 8/2005, Београд, 28. јануар 2005.

„Упутство за попуњавање и достављање потвда о смрти“, Институт за јавно здравље „Др Милан Јовановић Батут“, 15. октобар 2010.

http://www.batut.org.rs/download/uputstva/Uputstvo\%20potvrda\%20o\%20smrti.pdf. „Одлука о проглашењу болести COVID-19 изазване вирусом SARS-CoV-2 заразном болешћу (2020)“, Службени гласник PC, бр. 116/2020, Београд, 16. септембар 2020.

Liu, Yen-Chin, Kuo, Rei-Lin and Shih, Shin-Ru. "COVID-19: The first documented coronavirus pandemic in history", Biomedical Journal, Vol. 43, No. 4, 2020, pp. 328-333. 


\title{
ANALYSIS OF THE MORTALITY RATE OF THE COVID-19 INFECTIOUS DISEASE IN BELGRADE IN THE PERIOD OF MARCH-JUNE 2020, WITH AVAILABLE DATA TO 31 ${ }^{\text {st }}$ OF AUGUST 2020.
}

\begin{abstract}
The seriousness of every pandemic, besides mass illness, is measured through mortality and especially direct and indirect mortality. The objective of the paper: To present the available data on deaths during the epidemic of infectious disease COVID-19 in Belgrade for the period March-June 2020 and to determine whether there was an excess of general mortality and excess mortality from pneumonia compared to the average in March-June 2016-2019. Method and data: A descriptive epidemiological method was used in the paper. Data on mortality used data from the Center for Informatics and Statistics of the Institute of Public Health Belgrade from the database of deceased persons. Conclusion: After analyzing the mortality rate of the infectious disease COVID-19 in Belgrade, during the period of March-June 2020, it can be estimated that the mortality from this disease in Serbia is significant, and is higher than recorded during daily monitoring, so it is very important to be thoroughly researched. A thorough revision of mortality for the territory of the Republic of Serbia is proposed by the authors, according to the singular predeterment methodology in accordance with the WHO recommendations.
\end{abstract}

Key words: COVID-19, pandemic, mortality, DEM2 form, Belgrade 